\title{
Evaluation of Sanitation as a Preventive Measure of Foodborne Diseases in the Bakery Operation
}

\author{
Mária Vargová1 ${ }^{\text {, Katarína Veszelits Laktičová }}{ }^{2}$, Nad’a Sasáková ${ }^{3}$ and FrantišekZigo ${ }^{4 *}$ \\ ${ }^{1}$ Department of Public Veterinary Medicine and Animal Welfare, \\ University of Veterinary Medicine and Pharmacy, Košice, Slovakia \\ Email: Maria.Vargova [AT] uvlf.sk \\ ${ }^{2}$ Department of Public Veterinary Medicine and Animal Welfare, \\ University of Veterinary Medicine and Pharmacy, Koš ice, Slovakia \\ Email: Katarina.VeszelitsLakticova [AT] uvlf.sk \\ ${ }^{3}$ Department of Public Veterinary Medicine and Animal Welfare, \\ University of Veterinary Medicine and Pharmacy, Koš ice, Slovakia \\ Email: Nada.Sasakova [AT] uvlf.sk

\footnotetext{
${ }^{4}$ Department of Nutrition and Animal Hu sbandry, University of Veterinary Medicine and Pharmacy, Košice, Slovakia

*Corresponding author's email: Frantisek.Zigo [AT] uvlf.sk
}

\begin{abstract}
Every step from production through consumption can influence the microbiologyoffood products. Unsanitary equipment and unsufficient hygienic level in food industry lead to increased populations of microorganisms and can compromise quality and safety. Proper use of disinfectants can complement an effective sanitation program. Sanitation is an important part of the HACCP system, as its application significantly eliminates microorganisms in the production process. The system is an auxiliary control body for monitoring co mpliance with hygiene procedures. As a result of non-compliance with sanitation procedures, food products are conta minated and undesirable foodborne illnesses of the consumer occur. The epidemiology offoodborne diseases is rapidly changing as newly recognized pathogens emerge and well recognized pathogens increase in prevalence or become associated with new food vehicles. In this work, we focused on cleaning and disinfection of surfaces that significantly affect the hygienic safety of the resulting products. The purpose of sampling was to assess the effectiveness of disinfect ion in a bakery in order to prevent the occurrence of foodborne diseases. For disinfection, a $3 \%$ concentration of Savo disinfectant was used. Surface hygiene control was performed using microbiological swabs before the start of production, during production and after disinfection. Samples were taken from work surfaces floor, wall, table, tray and mixer. Disinfectant Savo was effective on floor, wall, tray and mixer where were detected significant decrea se of colony forming units of total count of bacteria, coliform bacteria and moulds after disinfection. On these mo nit ored surfaces no bacteria after disinfection was detected. On the table were detected 3 colony forming units of total count of bacteria after disinfection which represent decrease of microorganisms, in compare with numbers of microorganis ms before production. The results from the microbiological swabs shows that disinfectant Savo was able to dec rea se the number of colonies forming units afterdisinfection.
\end{abstract}

Keywords — Sanitation, HACCP, Disinfection, Foodborne Diseases.

ABBREVIATIONS: HACCP: Hazard Analysis Critical ControlPoint

\section{INTRODUCTION}

The basic requirement for food businesses is the production of safefood, which is influenced by the technological process at variou s stages, fromagricultural production through the food industry to food processing [1]. HACCP is a management s ystemin which food safety is addressed through the analy sis and control of chemical, biologic al and physical hazards from raw material production, handling, to manufacturing and distribution of the finis hed product.

Sanitation as a part of HACCP, is a proces s to reduce the number of microorganisms to a safe level, fromsurfaces that have been properly cleaned [2]. In connection with food industry, s anitation is the process of providing condition $\mathrm{s}$ that will ensure safe and wholesome products for human consumption [3]. Appropriate s anitation and proper selection of 
disinfectantis based on the knowledge of the resistance of microorg anisms to theeffect of the disinfectant, the efficacy of the disinfectants themselves and the potential negative impact on the environment [4]. The goal of disinfection is to destroy microorg anisms, this does not automatically mean killing all microorganisms, but reducing the $n$ umber to a level that is not normally harmful to health [5]. Dis infection is ineffective unless all surfaces have previously been thoroughly cleaned to remove interfering materials. Cleaning is therefore extremely important as part of a two-stage clean ing and disinfection program[6].

Des pite the high level of food safety in Europe, we encounter foodborne illness or food poisoning on a daily basis [7]. Food-borne dis eases represent very important health problemand an important cause of reduced economic gro wth. The contamination of the food products with the pathogens and its persistence, growth, multiplication has emerge d as an important public health concern. In contrast with most chemical hazardous compounds, the concentration of food pathogens changes during the processing, storage, and meal preparation.

Microorg anisms enter the production process fromdifferent sources and at differentstages of the process. W orker's skin and clothing, water, air, contact areas and additives are the most common factors contributing to the introduction of microorganis ms into the production environment [8]. Als o, non-contact surfaces such as floors, walls, ceiling s, ceiling beams and support devices are potential sources of microbial contamination. Packaging can also be a s ource of contamination. The hy gienic standard of food products can be assessed by the analy sis of the indicator micro org anisms [9]. The fecal coliforms, as for example Escherichia coli, are used as an indicator of the sanitary conditions [10]. Escherchia coli is a component of the fecal microbiota, its detection may indicate the potential occurrence of other microorganis ms which could be even more pathogenic to the man and both domestic and wild animals. It inclu des a broad variety of strains types, ranging fromthe highly pathog enic strains causing the world wide outbreaks of se vere disease to avirulent is olates which are part of the normal intes tinal microbiota, or which are well characterized and $\mathrm{s}$ afe laboratory strains $[11,12]$. SeveralE. coli types have been implicated with the diarrhoeal illness, a major public he alth problemworld wide, with over two million deaths occurring each year [13]. The presence of coliforms on the surfaces and in the products demonstrates possible contamination and indicates poor manufacturing practices and in ade quate factory hygiene standards [14]. The presence of coliformbacteria is generally an indication of fecal contamination of the water and food. Their quantification is therefore, an integral part of the quality as sess ment of food and water.

The purpose of sampling and subsequent laboratory analysis was to evaluate the effectiveness of disinfection in the bakery in order to prevent the occurrence of foodborne diseases. A properly designed and implemented Hazard Analy sis Critical Control Point system and appropriately selected sanitation procedures are necessary to achieve the desired effect.

\section{MATERIALS AND METHODS}

\subsection{Characteristics of bakery processing plant}

The evaluated bakery processing plant produce a wide range of bakery products. The hy gienic lev el of monitored surfaces - floor, wall, table, tray and mixer of pastry production (Figure 1,2) in the bakery operation was examine d and analyzed. The bakery was divided into several parts - Production hall with the bread making section and the pastry section; Packing hallincluding slicer and Dispatch hall. Swabs were taken fromProduction hall from the section of sweet pastry production. The bakery has a thoroughly developed and effective sanitation program, which is a part of HACCP system. All surfaces, machines and areas are cleaned and disinfected after the process of production.

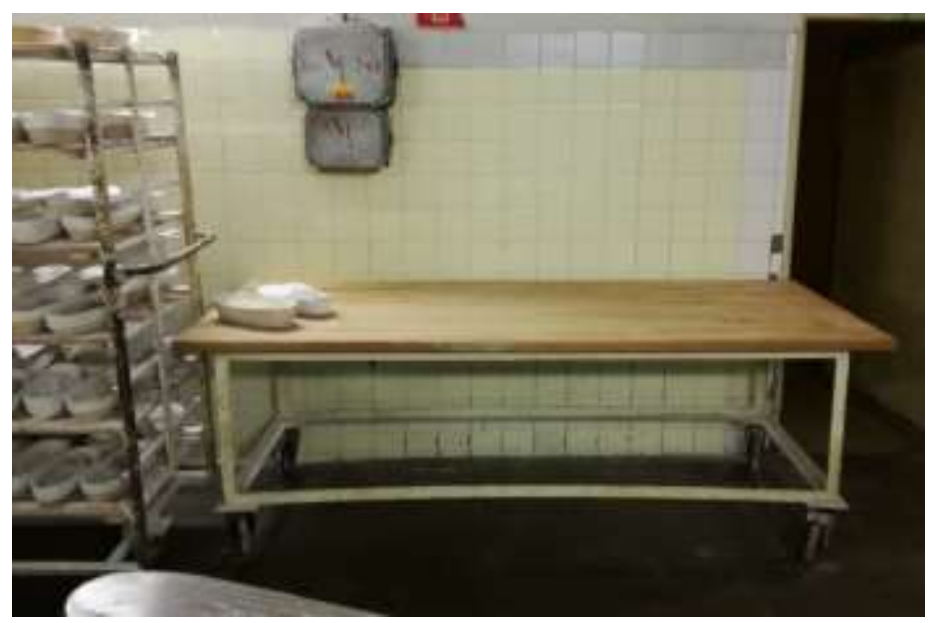

Figure 1: Work table - pastry section 


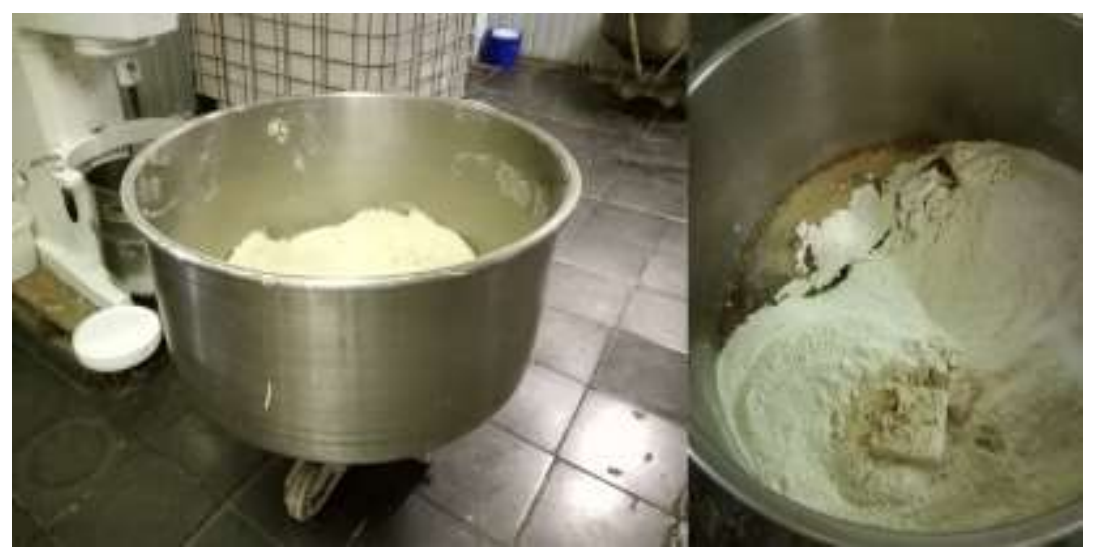

Figure 2: Mixer - pastry section

\subsection{Microbiological control of effectiveness of disinfection}

Samples were taken by microbiological s wabs from work surfaces - floor, wall, table, tray and mixer. Swabs were taken from evaluated surfaces before the start of production, during production and after disinfection. ISO 18593 and ISO 21527 are standards for the method of s ampling surfaces using prints and tampons $[15,16]$. The swabs were taken from area of $10 \times 10 \mathrm{~cm}$. Each one microbiological s wab was average value which was expres sed of $5 \mathrm{~s}$ wabs were taken from same place. The sampled areas were wiped with sterile cotton s wabs and the swabs were then placed in a sterile tube containing $10 \mathrm{ml}$ of sterile saline solution. Fromthis mixture $0.1 \mathrm{ml}$ was applied to the different agar plate s. Endo ag ar was used for coliformbacteria, Meat peptone agar was used for total count of bacteria and Sabouraud agar was used for yeas ts and molds. The results from the Endo ag ar and Meat peptoneagar were obtained after 24 hours incu bation at $37{ }^{\circ} \mathrm{C}$. The results fromthe Sabouraud agar were obtained after 5 days incubation at roomtemperature.

For disinfection of different surfaces was used disinfectant Savo in $3 \%$ concentration with exposure time 30 minutes. Savo is liquid cleaning and disinfecting agent. Disinfectant was used in liquid form, applicated by spraying, without heating. It contain sactive substance sodiumhypochlorite $\geq 1 \%-<5 \%$; sodiumhydroxide $\geq 0.5 \%-<2 \%$ and $<5 \%$ anionic surfactant, it is intended forcleaning any surfaces, inclu ding floors. The preparation has a broad-spect rum efficacy, is effectiveness against vegetative bacteria, fungi, poliovirus, adenoviruses, Bacillus subtilis, Mycobacterium.

Results were statistically processed using descriptive statis tical analysis of data.

\section{RESULTS}

Effectiveness of evaluated dis infectant Savo before the start of production, during production and after disinfection is shown in Table 1. Disinfectant Savo was effectiveon floor, wall, tray and mixer where were detected significant decrease of CFU of TCB, CB and moulds after disinfection. On these monitored surfaces no bacteria after disinfection was detected. On the table were detected $3 \mathrm{CFU}$ of TCB afterdisinfection which represent decrease of mic roo org anisms, in compare with numbers of microorganisms before production, but this amount of CFU doesn't represent hygienic risk for production. Presence of 3 colonies forming units of total count of bacteria could be cause due to unsuficient mech an ic al cleaning. Wood, as material which was used for table, is difficult to mechanicalclean because wood is a porous material, and due to this fact usage of wood in the food industry is under debate and wood is getting discriminated in many sectors. The results from the microbiological s wabs taken at the monitored bakery fromsection production of pastries shows that disinfectant Savo was able to decrease the number of colonies forming units after disinfection.

Table 1: Average values frommicrobiologicals wabs fromsection production of pastries

\begin{tabular}{|c|c|c|c|c|c|c|c|c|c|c|}
\hline \multirow[b]{2}{*}{ place of collection } & & \multicolumn{3}{|c|}{ before production } & \multicolumn{3}{|c|}{ during production } & \multicolumn{3}{|c|}{ after disinfection } \\
\hline & & $\begin{array}{l}\text { TCB } \\
\text { (CFU) }\end{array}$ & $\begin{array}{c}\text { CB } \\
\text { (CFU) }\end{array}$ & $\begin{array}{c}\mathrm{M} \\
\text { (CFU) }\end{array}$ & $\begin{array}{l}\text { TCB } \\
\text { (CFU) }\end{array}$ & $\begin{array}{c}\mathrm{CB} \\
\text { (CFU) }\end{array}$ & $\begin{array}{c}\mathbf{M} \\
(\mathbf{C F U})\end{array}$ & $\begin{array}{c}\text { TCB } \\
\text { (CFU) }\end{array}$ & $\begin{array}{c}\text { CB } \\
\text { (CFU) }\end{array}$ & $\begin{array}{c}\mathbf{M} \\
(\mathbf{C F U})\end{array}$ \\
\hline \multirow{5}{*}{$\begin{array}{l}\text { section production } \\
\text { of pastries }\end{array}$} & Floor & 3 & 1 & 1 & 15 & 0 & 2 & 0 & 0 & 0 \\
\hline & Wall & 0 & 0 & 0 & 10 & 0 & 0 & 0 & 0 & 0 \\
\hline & Table & 15 & 0 & 0 & 27 & 0 & 1 & 3 & 0 & 0 \\
\hline & Tray & 0 & 0 & 13 & 111 & 0 & 0 & 0 & 0 & 0 \\
\hline & Mixer & 0 & 0 & 0 & 8 & 0 & 0 & 0 & 0 & 0 \\
\hline
\end{tabular}

Abbreviations: $\mathrm{CFU}$ - colony forming units, $\mathrm{M}$ - moulds, $\mathrm{TCB}$ - total count of bacteria, $\mathrm{CB}$ - coliform bacteria 


\section{DISCUSION}

Maintaining a clean work environment is critical in preventing foodborne illness. Bacteria can grow on unsanit ary surfaces and then contaminate food. Sanitation is an applied science that inco rporates the principles of design, development, implementation, maintenance, restoration, and/or improvement of hygienic practices and conditions. Sanitation applications refer to hy gienic practices designed to maintain a clean and wholesome environment for food production, processing, preparation, and storage [17]. A sanitation plan is important in any food service preparation area. It ensures that all surfaces are cleaned on a regular basis and reduces the risks of transferring bacteria or other pathogens from an unclean surface to clean equipment such as cutting boards or tools [18]. An effective s an itation prog ram can improve product quality and shelf life because the microbial population can be reduced. An effective sanitation program includes regular cleaning and sanitizing of all equipment in a facility including heating, air conditioning, and refrigeration equipment. Dirty, clogged coils harbor microorg anisms and blowers and fans can spread flora throug hout the facility [17].

Food-borne illness is a major international problem and an important cause of reduced economic growth. The contamination of the food supply with the pathogens and its persistence, growth, multiplication and/or toxin prod uction has emerged as an important public health concern [19]. Most of these problems could be controlled with the efforts on the part of the food handlers, whether in a processing plant, a restaurant, and others [14]. Most outbreaks of fo od borne disease are microbiological in origin and their investigation usually require a microbiology laboratory. Outbreaks caused by chemically contaminated food also occur, although they are much less common than microbiological events [20]. In contrast with mostchemical hazardous compounds, the concentration of food pathogens changes during the processing, storage, and meal preparation, making it difficult to estimate the number of the microorganisms or the concentration of their toxins at the time of ingestion by the consumer [14]. Investigation of food establishments during a foodborne disease outbreak often require: interviewing managers; interviewing any employees who may have had a role in the processing or preparation of suspected foods; a review of employee records; a review of the ov erall operations and hygiene; food and environmental s amples a review of food worker health and hygiene, including s pecimens for analysis;an as sessment of the water systemand supply; measurement of temperatures, $\mathrm{pH}$ and water activity with ap prop riate equipment [20].

\section{CONCLUSION}

Food can become contaminated at any stage in the food chain, including at the farm, during animal slaughter, during processing, in restaurants, or at home. Because bacteria are everywhere, sanitation is a major factor in preventing foodborneillness. By keeping every thing hygienically clean that comes in contact with food, consumers can be assured they are helping to do their part to be food safe. According obtained results in practical conditions of bakery operation we can conclude that the disinfectant Savo which was used in $3 \%$ of concentration was effective on monitored surfaces floor, wall, tray and mixer, but on the table were found 3 colonies forming units of total count of bacteria after disinfection. Disinfection as a part of s anitation is considered as one of the most important activitie s in food in dustry, because it provide the hy gienic suitable environment for processing and all other activities, which is also confirme d by the results obtained in this work.

\section{ACKNOWLEDGEMENT}

This work was supported by Slovak grant KEGA no.004UVLF-4/2020.

\section{REFERENCES}

[1] Prousek J. Rizikové vlastnosti látok. Bratislava: Slovenská technická univerzita. 247 p. ISBN 80-227-1497-6, 2001.

[2] Fraser A. Define "cleaning" and "sanitizing" and the differences between the two procedures. In. www.foods afetysite.com. vol. 18, 2012.

[3] Skaarup T. Slaughterhouse cleaning and sanitation. In. Rome: Food and Agriculture Org anization of the United Nations, 1985, vol. 2018.

[4] Vargová M., Veszelits Laktičová K., Hromada R., Cimboláková I., Uher I., Papajová I. Sanitation and the environment. Intechopen. 2020.

[5] Wirtanen G, Salo S. Disinfection in food processing-efficacy testing of disinfectants. Environmental Science and Biotechnology, vol.2: no 2, pp. 293-306, 2003.

[6] Dvorak G. Disinfection 101. Center for Food Security and Public Health. Iowa State University, 2005.

[7] Šalgovičová D. a kol. Stredisko pre vyhodnocovanie výskytu cudzorodých látok. In Bulletin potravinárskeho výskumu (Bulletin ofFood Research). Vol. 39, no. 4, pp. 285-290, ISSN 0231-9950, 2000.

[8] Kornacki J.L. Principles of Microbiological Troubleshooting in the Industrial Food Processing Environment. [online]. McFarland:Springer. ISBN 978-1-4419-5517-3, 2010.

$<\mathrm{https} / / /$ books.google.sk/books?id=p5Mr69ii008C\&pg=PA4\&hl=sk\&source=gbs_toc_r\&cad=4\#v=onepage\&q\&f= false $>$ 
[9] Forsythe S.J.; Hayes P.R. Food Hygiene, Microbiology and HACCP. A Chapman and Hall Food Science Book. Aspen Publishers, Gaithers burg. 1988.

[10] Batt C., Batt C.A. Encyclopedia of Food Microbiology (Second Edition), Indicator org anisms. pp. 358-363, ISBN: 9780123847331, 2014.

[11] Sousa C.P. Pathogenicity mechanisms of prokaryotic cells: an evolutionary view. The Brazilian Journal of Infectious Diseases, vol. 7, pp. 23-31, 2003.

[12] Sousa C.P. The strategies of Escherichia coli pathotypes and health surveillance. Revisa, 1, pp. 65-70, 2005.

[13] W.H.O. Emerging foodborne diseases. Fact Sheet. pp. 124, 2002. Available at: $\underline{w w w . w h o . i n t / i n f f s / e n / f a c t ~ 124 . h t m l . ~}$

[14] Sous a C.P. The impact of food manufacturing practices on food borne dis eases June 2008Brazilian Archives of Biology and Technology

[15] ISO 18593: Microbiology of food and animal feeding stuffs - Horizontalmethods for sampling techn iques from surfaces u sing contact plates and s wabs. International Org anization for Standardization, 2004.

[16] ISO 21527: Microbiology of food and animal feeding stuffs -- Horizontal method for the enumeration of yeasts and moulds --Part 1: Colony count technique in products with water activity greater than 0,95, 2008.

[17] Marriott N.G., Gravani R.B. Principles of Food Sanitation, Fifth Edition. ISBN-10: 0-387-25025-5, pp. 15-30,2006.

[18] Victoria B.C. Food Safety, Sanitation, and Personal Hygiene. ISBN: 978-1-7753524-6-4, 2015.

[19] Newell D.G., Koopmans M., Linda P.B., Duizer V.E. Food-borne diseases - The challenges of 20years a g o still persist while new ones continue to emerge. 2010.

[20] WHOLibrary Cataloguing-in-Publication Data Foodborne disease outbreaks : guidelines for investigation and control. ISBN 978924154722 2, pp. 37, 2008 